\title{
NATURAL ORGANIC COMPOUNDS AS TRACERS FOR BIOMASS \\ COMBUSTION IN AEROSOLS
}

\author{
B. R. T. Simoneit ${ }^{1}$, M. Radzi bin Abas 2 , G. R. Cass 3 , W. F. Rogge ${ }^{4}$, \\ M. A. Mazurek, L. J. Standley 5 , and L. M. Hildemann 6 \\ Environmental Chemistry Division \\ Department of Applied Science \\ Brookhaven National Laboratory \\ Upton, NY 11973
}

August 1995

For inclusion in

Biomass Burning, Proc. Chapman Conference, Williamsburg, VA, March 13-17, Levine, J. S., ED., MTT Press, 1995.

1 College of Oceanic and Atmospheric Sciences, Oregon State University, Corvallis, OR 97331-5503

2 Department of Chemistry, University of Malaya, Kuala Lumpur 59100, Malaysia

3 Environmental Engineering Science Department, California Institute of Technology, Pasadena, CA 91125

4 Department of Civil \& Environ. Engineering, Florida International University, University Park, FL 33199

5 Stroud Water Research Center, Academy of Natural Sciences, Avondale, PA 19311

6 Department of Civil Engineering, Stanford University, Stanford, CA 94305

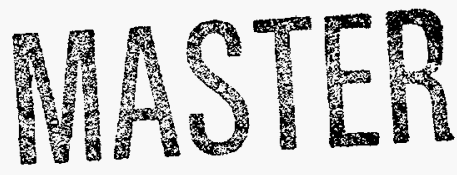

This research was performed under the auspices of the U.S. Department of Energy under Contract No. DE-AC02-76CH00016. 


\section{ABSTRACT}

Biomass combustion is an important primary source of carbonaceous particles in the global atmosphere. Although various molecular markers have already been proposed for this process, additional specific organic tracers need to be characterized.

The injection of natural product organic tracers to smoke occurs primarily by direct volatilization/steam stripping and by thermal alteration based on combustion temperature. The degree of alteration increases as the burn temperature rises and the moisture content of the fuel decreases. Although the molecular composition of organic matter in smoke particles is highly variable, the molecular structures of the tracers are generally source specific.

The homologous compound series and biomarkers present in smoke particles are derived directly from plant wax, gum and resin by volatilization and secondarily from pyrolysis of biopolymers (e.g., cellulose, lignin, cutin, suberin), wax, gum and resin. The complexity of the organic components of smoke aerosol is illustrated with examples from controlled burns of temperate and tropical biomass fuels. Burning of biomass from temperate regions (i.e., conifers) yields characteristic tracers from diterpenoids as well as phenolics and other oxygenated species, which are recognizable in urban airsheds. The major organic components of smoke particles from tropical biomass are straight-chain, aliphatic and oxygenated compounds and triterpenoids. Several compounds (e.g., amyrones, friedelin, aromatic A-noroleananes and other thermal derivatives from triterpenoids, lignin phenols) are potential key indicators for smoke components from combustion of such biomass. The precursor to product approach of organic geochemistry can be applied successfully to provide tracers for studying smoke plume chemistry and dispersion.

\section{INTRODUCTION}

Biogenic organic matter, consisting predominantly of lipids, soot and humic and fulvic acids, is now firmly established as a major carbonaceous fraction in atmospheric particles found in urban, rural and remote locales [i.e., Arpino et al., 1972; Broddin et al., 1980; Cox et al., 1982; Duce et al., 1983; Eichmann et al., 1979, 1980; Gagosian et al., 1981, 1982, 1987; Marty and Saliot, 1982; Matsumoto and Hanya, 1980; Mazurek and Simoneit, 1984; Mazurek et al., 1989; 


\section{DISCLAIMER}

Portions of this document may be illegible in electronic image products. Images are produced from the best available original document. 
Ohta and Handa, 1985; Rogge et al., 1993a; Simoneit, 1977, 1979, 1980, 1984a,b, 1985, 1986, 1989; Simoneit and Mazurek, 1982, 1989; Simoneit et al., 1977, 1980, 1983, 1988, 1990, 1991a,b,c]. However, in comparison to the relatively extensive studies that have been carried out on hydrocarbons of both biogenic and anthropogenic origins in these aerosols, only limited molecular information is available on polar compounds [e.g., Gagosian et al., 1987; Hawthorne et al., 1988, 1989, 1992; Mazurek et al., 1989; Rogge et al., 1993a,b; Schneider et al., 1983; Simoneit, 1985, 1989; Simoneit and Mazurek, 1982; Simoneit et al., 1983, 1988, 1993].

Biomass combustion is an important primary source of many trace substances that are reactants in atmospheric chemistry and of soot particulate matter which decreases visibility and absorbs incident radiation [e.g., Crutzen et al., 1985; Levine, 1991; Lobert et al., 1990; Seiler and Crutzen, 1980]. Thus, there is a need to demonstrate additional specific tracers for this input process and a limited number of molecular markers have been proposed.

This additional input of biogenic organic matter to the troposphere (urban, rural and remote) from biomass combustion occurs by natural, as well as man-made, fires. Thermallyaltered (pyrolysis) and directly-emitted molecular markers may be used as indicators. This concept has been applied preliminarily to tracing biomass burning in Oregon [Standley and Simoneit, 1987, 1990, 1994], in China [Simoneit et al., 1991b], and Amazonia, Brazil [Abas et al., 1995]. For example, retene, a thermal alteration product from resin diterpenoids (e.g., abietic acid), has been found in aerosols in Elverum, Norway and in Oregon, and at trace levels in Los Angeles, California [Ramdahl, 1983; Mazurek et al., 1989; Standley and Simoneit, 1987, 1990, 1994], and China [Simoneit et al., 1991b]. Retene was not detectable in aerosols of the Harmattan or in urban samples of Nigeria, nor in rural aerosols of SE Australia, because conifer wood is not used for fuel in those areas [Simoneit et al., 1988, 1991c]. Since there is no major non-combustion source for retene, it is useful as an indicator of wood burning, especially conifer, but is not always concentrated enough for detection. Thus, additional tracers of thermally-altered and directlyemitted natural products need to be characterized to assign input sources of organic matter from biomass combustion to aerosols. 


\section{EXPERIMENTAL METHODS}

\section{Samples}

Large samples of smoke particulate matter were acquired by high volume filtration on prebaked quartz fiber filters and the complementary fine particle fractions $\left(d_{p}<2 \mu \mathrm{m}\right)$ were collected after appropriate dilution on small prebaked quartz fiber filters ( $47 \mathrm{~mm}$ diam.) [e.g., Hildemann et al., 1991 a; Standley and Simoneit, 1987]. Data are discussed from various types of smoke samples consisting of (1) the fine fraction from pine and oak wood combustion in a fireplace [Hildemann et al., 1991b; Rogge et al., 1993a; unpublished data], (2) controlled burns of forest litter in Oregon [Standley and Simoneit, 1987, 1994], (3) alder wood combustion in a wood stove [Standley and Simoneit, 1990], (4) various grass and chaparral fires, and (5) a controlled fire of tropical forest litter in Amazonia, Brazil [Abas et al., 1995].

\section{Lipid Isolation and Separation}

The filters with particulate matter were extracted with methylene chloride $\left(\mathrm{CH}_{2} \mathrm{Cl}_{2}\right)$ or other polar solvent mixtures within the filter storage jars [Simoneit and Mazurek, 1982]. The solvent extracts were filtered for the removal of insoluble particles. Filtrates were first concentrated on a rotary evaporator and then using a stream of filtered nitrogen gas to a volume of approximately $5 \mathrm{~mL}$. Volumes were then adjusted to $5.0 \mathrm{~mL}$ exactly by addition of $\mathrm{CH}_{2} \mathrm{Cl}_{2}$.

Typically, an aliquot $(2.5 \mathrm{~mL}$ ) of the filtrate was transferred to a $5 \mathrm{~mL}$ heavy-walled, conical vial, and $30 \mu \mathrm{L}$ perdeutero- $n$-tetracosane $(90 \mu \mathrm{g} / \mathrm{mL})$ was added as internal standard. The mixture was reduced in volume to $500 \mu \mathrm{L}$ and $3.0 \mathrm{~mL}$ of $\mathrm{BF}_{3}$-methanol (Pierce) was added. The vial was capped and heated to approximately $60^{\circ} \mathrm{C}$ for 10 minutes to esterify carboxylic acids. After cooling the mixture was transferred to a separatory funnel with $30 \mathrm{~mL}$ of hexane and washed twice with saturated $\mathrm{NaCl}$ solution, discarding the aqueous layer. The organic layer was dried over $\mathrm{Na}_{2} \mathrm{SO}_{4}$. The solvent was evaporated under nitrogen to almost dryness and reconstituted with a known volume of hexane (final volume $500 \mu \mathrm{L}$ ). The derivatized extract was subjected to thin layer 
chromatography (TLC) using silica-gel plates $(0.25 \mathrm{~mm}$, Alltech) and eluted with a mixture of hexane and diethyl ether (9:1). The TLC plates had been cleaned prior to use by repetitive elutions with methanol and $\mathrm{CH}_{2} \mathrm{Cl}_{2}$, and before sample application they were activated in an oven at $120^{\circ} \mathrm{C}$ for 45 minutes. An aliquot of the total extract was quantified by evaporation to dryness and weighing, and the fractions were quantified by gas chromatographic analyses.

The TLC fractions and the total and methylated extract fractions were subjected to gas chromatographic (GC) and gas chromatography-mass spectrometric (GC-MS) analyses. Alcohol fractions were converted to the trimethylsilyl ethers prior to GC and GC-MS analysis by reaction with N,O-bis-(trimethylsilyl)-trifluoroacetamide (BSTFA) for approximately $30 \mathrm{~min}$ at $\sim 70^{\circ} \mathrm{C}$ under a nitrogen atmosphere.

\section{Lipid Analyses}

The GC analyses were carried out on a Hewlett-Packard Model 5840A gas chromatograph using a $25 \mathrm{~m} \times 0.20 \mathrm{~mm}$ i.d. fused silica capillary column coated with DB-5 ( $\mathrm{J}$ and W, Inc.). The GC-MS analyses were conducted on a Finnigan Model 4021 quadrupole mass spectrometer interfaced directly with a Finnigan Model 9610 gas chromatograph and equipped with a fused silica capillary column coated with DB-5 (30 $\mathrm{m} \times 0.25 \mathrm{~mm}$ i.d.). The GC and GC-MS operating conditions were as follows: isothermal at $65^{\circ} \mathrm{C}$ for $2 \mathrm{~min}$ for $\mathrm{GC}$ only, temperature program 65 $310^{\circ} \mathrm{C}$ at $4^{\circ} \mathrm{C}$ per minute, hold isothermal at $310^{\circ} \mathrm{C}$ for $60 \mathrm{~min}$ and using helium as carrier gas. Mass spectrometric data were acquired and processed using a Finnigan-Incos Model 2300 data system. Molecular markers were identified by GC and GC-MS comparison with authentic standards and characterized mixtures. Unknown compounds were characterized by interpretation of their mass spectrometric fragmentation pattern.

\section{RESULTS AND DISCUSSION}

\section{Combustion Process}

Combustion by burning other than incineration at ultrahigh temperatures is not completely destructive to the organic matter in the fuels. Thus, the injection of organic tracer compounds into 
smoke occurs primarily by direct volatilization/steam stripping and by thermal alteration based on combustion temperature. The degree of alteration of organic matter increases as the burn temperature rises and the moisture content of the fuel decreases. Although the molecular composition of organic matter in smoke particles is highly variable, the molecular tracers are generally still source specific [e.g., Hawthorne et al., 1988, 1989, 1992; Standley and Simoneit, 1987, 1990, 1994, Abas et al., 1995]. For example, retene, a thermal alteration product from resin diterpenoids (e.g., abietic acid) as described above, has been found in aerosols in Norway and Oregon, and at trace levels in some urban areas [Ramdahl, 1983; Mazurek et al., 1991; Standley and Simoneit, 1987, 1994; Simoneit et al., 1991a]. Retene was not detectable in aerosols of geographic regions where conifers do not grow to be used as fuel [Abas et al., 1995; Simoneit et al., 1988, 1991b]. Since there is no known non-combustion source for retene, it is useful as an indicator of conifer wood burning, but does not always have an ambient concentration adequate for detection. Definition of additional tracers of thermally-altered and directly-emitted natural products will aid the assessment of the impact of biomass combustion on aerosols.

\section{Organic Tracers}

Smoke particles contain homologous compound series and biomarkers which are derived directly from plant wax, gum and resin by volatilization and secondarily from pyrolysis of biopolymers (e.g., cellulose, lignin, cutin, suberin), wax, gum and resin. Biomarkers or molecular tracers are the indicator compounds best utilized for confirmation of genetic sources of carbonaceous fractions in smoke emissions. As applied here, biomarkers are utilized as indicators of origins from natural product compounds of vegetation and their altered derivatives (residues) by partial combustion. The complexity of the organic components of smoke aerosol particles will be illustrated with three examples.

\section{Conifer Wood Smoke}

The first example demonstrates that diterpenoids are excellent indicators for smoke from burning of gymnosperm wood [e.g., conifers, Ramdahl, 1983; Standley and Simoneit, 1987, 
1994]. Resin acids such as abietic or pimaric acids are produced by conifers. These compounds and their derivatives at various stages of thermal alteration have been found in ambient aerosols [Simoneit and Mazurek, 1982; Simoneit, 1989] and in smoke from slash and wood burning [Standley and Simoneit, 1987, 1994; Simoneit et al., 1993]. This can be illustrated with the mass fragmentograms for the extract fractions (acids as methylated derivatives) of fine aerosol particles from a fireplace where pine wood was burned [Fig. la, b; Rogge et al., unpublished data; Simoneit et al., 1993]. The major diterpenoid compounds in the smoke are pimaric (2, chemical structures are shown in Appendix 1), sandaracopimaric (3), isopimaric (4), dehydroabietic (5), and abietic (6) acids (Fig. 1a, b). Dehydroabietic acid can be regarded as an altered product from resin acids and the other diterpenoid acids are directly volatilized unaltered marker compounds. An aerosol sample taken during winter in Los Angeles is also shown for comparison (Fig. 1c, d). Dehydroabietic acid is the dominant diterpenoid marker and the other resin acids are present at reduced levels. $\Delta^{8,15}$-Pimaradien-18-oic acid $(1$, Fig. 1$)$ appears to be an alteration product due to double bond migration, and retene and other hydrocarbon diterpenoid derivatives occur at trace levels only. This demonstrates that diterpenoid acids are recognizable tracers in the urban atmosphere for wood smoke.

\section{Mixed Temperate Forest Burn}

The second example is smoke from a controlled slash burn of mixed temperate forest illustrating the ketones formed by combustion [Standley and Simoneit, 1987]. The ketone fraction consists primarily of $n$-alkan-2-ones, $n$-alkanals, and triterpenones (Fig. 2). The $n$-alkan-2-ones range from $C_{16}$ to $C_{33}$, with a $C_{\max }=27$ and strong odd-to-even carbon number preference. The $n$-alkanals range from $C_{19}$ to $C_{31}$, with a $C_{\max }=23$ and also a strong odd-to-even carbon number preference. Both $n$-alkanones and $n$-alkanals are partial oxidation products from alkanols, alkanes and other aliphatic moieties, analogous as is observed in laboratory hydrous pyrolysis experiments [Leif and Simoneit, 1995]. The triterpenones are mainly the amyrones, taraxerone, lupenone and a friedelin derivative (Fig. 2b). They are either natural products or low temperature oxidation 
products from the respective triterpenol precursors, and are characteristic of their higher plant sources.

\section{Amazon Biomass Smoke}

The third example is a smoke sample from burning of composited vegetation in Amazonia [Abas et al., 1995] and the various lipid fractions extracted from the particulate matter are shown in Fig. 3. The total extract is comprised mainly of $n$-alkanoic acids, $n$-alkanes, polynuclear aromatic hydrocarbons (PAH), and triterpenoids. The $n$-alkanes range from $\mathrm{C}_{17}$ to $\mathrm{C}_{37}$ with a $\mathrm{C}_{\max }=$ 29/31 and high odd carbon number preference (Fig. 3b), which is similar as reported for aerosols from the Amazon region, indicating that alkanes from burning are indistinguishable from plant wax alkanes in the ambient aerosol [Simoneit et al., 1990]. The same is the case for the $n$-alkanoic acids and $n$-alkanols (Fig. $3 c, f$ ).

More specific homologous aliphatic tracers for combustion are the $n$-alk- 1 -enes, $n$-alkan-2ones and $\alpha, \omega$-alkanedioic acids (Fig. $3 b, d, e)$. For example, the major series of $n$-alk-1-enes present ranges from $C_{17}$ to $C_{35}$, with $C_{\max }=22$ (minor at 29/31) and a slight even carbon number predominance $(\mathrm{CPI}=0.8$, Fig. $4 \mathrm{~b})$. Alkenes are not dominant components in aerosols or plant waxes. The origin of these compounds is inferred to be from the biomass fuel, and based on their carbon number distribution primarily from $n$-alkanols by dehydration ( $n$-alkan-1-ols are easily dehydrated to $n$-alk-1-enes by high temperatures) and to a minor degree from the $n$-alkanes by oxidation during incomplete combustion (compare Fig. $4 \mathrm{~b}$ with $\mathrm{c}$ and a, respectively). The even carbon number dominance and $\mathrm{C}_{\max }=22$ are derived from the $n$-alkanol distribution, and the minor dominance of $n-C_{29}$ and $n-C_{31}$ reflects the dehydrogenation of the $n$-alkanes.

The aliphatic hydrocarbon fraction contains a group of derivatives from the amyrins (e.g., $\beta-7$ ) (peaks 1-6, Fig. 3b, structures also shown in Fig. 5) which are various triterpadienes (e.g., ursa-2,12-diene), noroleanene, norursene, and diaromatic A-noroleananes and A-norursanes [Abas et al., 1995]. These compounds are not known as natural products and are therefore indicators for combustion of biomass containing amyrin precursors. The $\alpha$ - and $\beta$-amyrins ( 7 ) are the predominant biomarkers in the total smoke lipids (Fig. 3f), and $\alpha$ - and $\beta$-amyrones (8) (mild 
oxidation products of amyrins) and friedelin (9) are also significant (Fig. 3d, f). Phytosterols from plant waxes are trace components in this smoke sample and consist mainly of $\beta$-sitosterol (10) with lesser amounts of other $\mathrm{C}_{29}$ and $\mathrm{C}_{28}$ isomers. This is characteristic as observed for other smoke emissions from vegetation [e.g., Simoneit et al., 1983, 1993].

The PAH are pyrogenic molecular markers in smoke, where the unsubstituted analogs are usually the characteristic compounds of higher temperature combustive processes. Major amounts of PAH are found in this sample (Figs. 3c and 6a, peaks 1-15) and consist primarily of phenanthrene ( $I)$, methylenephenanthrene, methylphenanthrenes (2-5), fluoranthene $(0)$, pyrene (7), and chrysene (9), and traces of benzofluoranthenes (10), benzo(e\&a)pyrenes, anthanthrene, indenopyrene, benzo(ghi)perylene, and coronene. Oxy-PAH are also significant (Figs. 3e and 6b, peaks 16-23) and the predominant compounds are fluorenone (16), anthra-9,10-quinone (17), cyclopenta(def)phenanthren-4-one (18,11), benzo(a)fluoren-11-one $(20,12)$, benzanthrone (13), and naphthanthrone $(23,14)$, with minor amounts of methylanthra-9,10-quinones, benzo(c)fluoren-7-one and benz(a)anthra-7,12-quinone. The chemical structures of the PAH and oxy-PAH cannot be correlated to specific sources, they are resynthesis products from any high temperature combustive process using organic matter as fuel.

Phenolic products from the pyrolytic breakdown of lignin in vegetation have been proposed as tracers specific for plant classes (taxa) [e.g., Hawthorne et al., 1988, 1989, 1992; Simoneit et al., 1993]. The dominant markers for lignin in this smoke sample found in fraction 6 (Fig. 3f) are vanillin (15), vanillic acid (16), syringaldehyde (17), syringic acid (18), and guaiacylacetone (19), with traces of various other phenolic products. This group of tracers confirms the relative contribution to the smoke from each biomass taxon in the fuel [Abas et al., 1995].

\section{CONCLUSION}

The major organic components of smoke particles from tropical biomass are straight-chain, aliphatic and oxygenated compounds and triterpenoids from vegetation waxes, resins/gums, and biopolymers. Several compounds (e.g., amyrones, friedelin, aromatic A-noroleananes, and other thermal derivatives from triterpenoids and from lignin - syringaldehyde, vanillin, syringic acid, 
vanillic acid) are potential key indicators for smoke components from combustion of such biomass. Burning of biomass from temperate regions (i.e., conifers) yields characteristic tracers from diterpenoids as well as phenolics and other oxygenated species, which are recognizable in urban airsheds. Biomass combustion smoke from tropical areas (i.e., hardwoods) also yields characteristic tracers. The precursor to product approach of organic geochemistry can be applied successfully to delineate tracers (biomarkers) for the environmental process of biomass combustion.

\section{ACKNOWLEDGMENTS}

This research was supported by the U.S. Environmental Protecton Agency under agreement R-819714-01-0 (to GRC) and XXXXXX (to BRTS) and by the South Coast Air Quality Management District. This manuscript has not been subject to the EPA's peer and policy review, and hence does not necessarily reflect the views of the EPA.

\section{REFERENCES}

Abas, M.R., B.R.T. Simoneit, V. Elias, J.A. Cabral and J.N. Cardoso (1995). Composition of higher molecular weight organic matter in smoke aerosol from biomass combustion in Amazonia. Chemosphere 30, 995-1015.

Arpino, P., A. van Dorsselaer, K.D. Sevier and G. Ourisson (1972). Cires aeriènnes dans une forêt de Pins. C.R. Acad. Sc. (Paris) 275D, 2837-2840.

Broddin, G., W. Cautreels and D. van Cauwenberghe (1980). On the aliphatic and polyaromatic hydrocarbon levels in urban and background aerosols from Belgium and the Netherlands. Atmos. Environ. 14, 895-910.

Cox, R.E., M.A. Mazurek and B.R.T. Simoneit (1982). Lipids in Harmattan aerosols of Nigeria. Nature 296, 848-849. 
Crutzen, P.J., A. C. Delany, J. Greenberg, P. Haagenson, L. Heidt, R. Lueb, W. Pollock, W. Seiler, A. Wartburg and P. Zimmerman (1985). Tropospheric chemical composition measurements in Brazil during the dry season. J. Atmosph. Chem. 2, 233-256.

Duce, R.A., V.A. Mohnen, P.R. Zimmerman, D. Grosjean, W. Cautreels, R. Chatfield, R. Jaenicke, J.A. Ogren, E.D. Pellizzari and G.T. Wallace (1983). Organic material in the global troposphere. Rev. Geophys. Space Phys. 21, 921-952.

Eichmann, R., P. Neuling, G. Ketseridis, J. Hahn, R. Jaenicke and C. Junge (1979). n-Alkane studies in the troposphere-I: Gas and particulate concentrations in North Atlantic air. Atmosph. Environ. 13, 587-599.

Eichmann, R., G. Ketseridis, G. Schebeske, R. Jaenicke, J. Hahn, P. Warneck and C. Junge (1980). n-Alkane studies in the troposphere-II: Gas and particulate concentrations in Indian Ocean air. Atmosph. Environ. 14, 695-703.

Gagosian, R.B., E.T. Peltzer and J.T. Merrill (1987). Long-range transport of terrestrially derived lipids in aerosols from the South Pacific. Nature 325, 800-803.

Gagosian, R.B., E.T. Peltzer and O.C. Zafiriou (1981). Atmospheric transport of continentally derived lipids to the tropical North Pacific. Nature 291, 321-324.

Gagosian, R.B., O.C. Zafiriou, E.T. Peltzer and J.B. Alford (1982). Lipids in aerosols from the tropical North Pacific: Temporal variability. J. Geophys. Res. 87, 11133-11144.

Hawthorne, S.B., D.J. Miller, R.M. Barkley and M.S. Krieger (1988). Identification of methoxylated phenols as candidate tracers for atmospheric wood smoke pollution. Environ. Sci. Technol.22, 1191-1196.

Hawthorne, S.B., M.S. Krieger, D.J. Miller and M.B. Mathiason (1989). Collection and quantitation of methoxylated phenol tracers for atmospheric pollution from residential wood stoves. Environ. Sci. Technol. 23, 470-475.

Hawthorne, S.B., D.J. Miller, J.J. Langenfeld and M.S. Krieger (1992). PM-10 high-volume collection and quantitation of semi- and nonvolatile phenols, methoxylated phenols, alkanes 
and polycyclic aromatic hydrocarbons from winter urban air and their relationship to wood smoke emissions. Environ. Sci. Technol. 26, 2251-2262.

Hildemann, L.M., G.R. Markowski and G.R. Cass (1991a). Chemical composition of emissions from urban sources of fine organic aeorsol. Environ. Sci. Technol. 25, 744-759.

Hildemann, L.M., M.A. Mazurek, G.R. Cass and B.R.T. Simoneit (1991b). Quantitative characterization of urban sources of organic aerosol by high-resolution gas chromatography. Environ. Sci. Technol. 25, 1311-1325.

Leif, R.N. and B.R.T. Simoneit (1995). Ketones in hydrothermal petroleums and sediment bitumen from Guaymas Basin, Gulf of California. Org. Geochem., submitted for publication.

Levine, J.S. (1991). Introduction: Global biomass burning: Atmospheric, climatic, and biospheric implications. In: Global Biomass Burning: Atmospheric, Climatic, and Biopheric Implications, J.S. Levine (ed.), MIT Press, Cambridge, MA, pp. xxv-xxx.

Lobert, J.M., D.H. Scharffe, W.M. Hao and P.J. Crutzen (1990). Importance of biomass burning in the atmospheric budgets of nitrogen-containing gases. Nature 346, 552-554.

Marty, J.-C. and A. Saliot (1982). Aerosols in equatorial Atlantic air: $\underline{n}$-alkanes as a function of particle size. Nature 298, 144-147.

Matsumoto, G. and T. Hanya (1980). Organic constituents in atmospheric fallout in the Tokyo area. Atmosph. Environ. 14, 1409-1419.

Mazurek, M.A. and B.R.T. Simoneit (1984). Characterization of biogenic and petroleum-derived organic matter in aerosols over remote, rural and urban areas. In: Identification and Analysis of Organic Pollutants in Air, ACS Symp., L.H. Keith (ed.), Ann Arbor Science/Butterworth Publishers, Woburn, MA, pp. 353-370.

Mazurek, M.A., B.R.T. Simoneit and G.R. Cass (1989). Interpretation of high-resolution gas chromatography and high resolution gas chromatography/mass spectrometry data acquired from atmospheric organic aerosol samples. In: Proc. 3rd Int. Conf. Carbonaceous Particles in the Atmosphere, Aerosol Sci. Technol. 10, 408-420. 
Mazurek, M.A., G.R. Cass and B.R.T. Simoneit (1991). Biological input to visibility-reducing aerosol particles in the remote arid southwestern United States. Environ. Sci. Technol. 25, 684-694.

Ohta, K. and N. Handa (1985). Organic components in size-separated aerosols from the western North Pacific. J. Oceanogr. Soc. Jap. 41, 25-32.

Ramdahl, T. (1983). Retene - a molecular marker wood combustion in ambient air. Nature 306, $580-582$.

Rogge, W.F., M.A. Mazurek, L.M. Hildemann, G.R. Cass and B.R.T. Simoneit (1993a). Quantification of organic aerosols on a molecular level: Identification, abundance and seasonal variation. Proc. Fourth Int. Conf. on Carbonaceous Particles in the Atmosphere. Atmosph. Environ. 27A, 1309-1330.

Rogge, W.F., L.M. Hildemann, M.A. Mazurek, G.R. Cass and B.R.T. Simoneit (1993b). Sources of fine organic aerosol: 4. Particulate abrasion products from leaf surfaces of urban plants. Environ. Sci. Technol. 27, 2700-2711.

Schneider, J.K., R.B. Gagosian, J.K. Cochran and T.W. Trull (1983). Particle size distributions of n-alkanes and $210 \mathrm{~Pb}$ in aerosols off the coast of Peru. Nature 304, 429-432.

Seiler, W. and P.J. Crutzen (1980). Estimates of gross and net fluxes of carbon between the biosphere and the atmosphere from biomass burning. Climatic Change 2, 207-247.

Simoneit, B.R.T. (1977). Organic matter in eolian dusts over the Atlantic Ocean, Proceedings of Symposium on Concepts in Marine Organic Chemistry. Mar. Chem. 5, 443-464.

Simoneit, B.R.T. (1979). Biogenic lipids in eolian particulates collected over the ocean. In: Proceedings Carbonaceous Particles in the Atmosphere, T. Novakov (ed.), NSF-LBL, pp. 233-244.

Simoneit, B.R.T. (1980). Eolian particulates from oceanic and rural areas--Their lipids, fulvic and humic acids and residual carbon. In: Advances in Organic Geochemistry 1979, A.G. Douglas and J.R. Maxwell (eds.), Pergamon Press, Oxford, pp. 343-352. 
Simoneit, B.R.T. (1984a). Organic matter of the troposphere: III--Characterization and sources of petroleum and pyrogenic residues in aerosols over the Western United States. Atmosph. Environ. 18, 51-67.

Simoneit, B.R.T. (1984b). Application of molecular marker analysis to reconcile sources of carbonaceous particulates in tropospheric aerosols. In: Proc. 2nd Int. Conf. Carbonaceous Particles in the Atmosphere. Science of the Total Environ. 36, 61-72.

Simoneit, B.R.T. (1985). Application of molecular marker analysis to vehicular exhaust for source reconciliations. Int. J. Environ. Anal. Chem. 22, 203-233.

Simoneit, B.R.T. (1986). Characterization of organic constituents in aerosols in relation to their origin and transport: A review. Int. J. Environ. Anal. Chem. 23, 207-237.

Simoneit, B.R.T. (1989). Organic matter of the troposphere-V: Application of molecular marker analysis to biogenic emissions into the troposphere for source reconciliations. J.Atmosph. Chem. 8, 251-275.

Simoneit, B.R.T. and M.A. Mazurek (1982). Organic matter of the troposphere--II. Natural background of biogenic lipid matter in aerosols over the rural western United States. Atmosph. Environ. 16, 2139-2159.

Simoneit, B.R.T. and M.A. Mazurek (1989). Organic tracers in ambient aerosols and rain. In: Proc. 3rd Int. Conf. Carbonaceous Particles in the Atmosphere. Aerosol Sci. Technol. 10, 267-291.

Simoneit, B.R.T., R. Chester and G. Eglinton (1977). Biogenic lipids in particulates from the lower atmosphere over the eastern Atlantic. Nature 267, 682-685.

Simoneit, B.R.T., M.A. Mazurek and T.A. Cahill (1980). Contamination of the Lake Tahoe air basin by high molecular weight petroleum residues. J. Air Poll. Contr. Assoc. 30, 387-390.

Simoneit, B.R.T., M.A. Mazurek and W.E. Reed (1983). Characterization of organic matter in aerosols over rural sites: Phytosterols. In: Advances in Organic Geochemistry 1981, M. Bjorøy et al. (eds.), J. Wiley and Sons Ltd., Chichester, pp. 355-361. 
Simoneit, B.R.T., R.E. Cox and L.J. Standley (1988). Organic matter of the troposphere-IV:

Lipids in Harmattan aerosol particles of Nigeria. Atmosph. Environ. 22, 983-1004.

Simoneit, B.R.T., J.N. Cardoso and N. Robinson (1990). An assessment of the origin and composition of higher molecular weight organic matter in aerosols over Amazonia.

Chemosphere 21, 1285-1301.

Simoneit, B.R.T., J.N. Cardoso and N. Robinson (1991a). An assessment of terrestrial higher molecular weight lipid compounds in air particulate matter over the South Atlantic from about 30-70 S. Chemosphere 23, 447-465.

Simoneit, B.R.T., G. Sheng, X. Chen, J. Fu, J. Zhang and Y. Xu (1991b). Molecular marker study of extractable organic matter in aerosols from urban areas of China. Atmosph. Environ. 25A, 2111-2129.

Simoneit, B.R.T., P.T. Crisp, M.A. Mazurek and L.J. Standley (1991c). Composition of extractable organic matter of aerosols from the Blue Mountains and southeast coast of Australia. Environ. Internat. 17, 405-419.

Simoneit, B.R.T., W.F. Rogge, M.A. Mazurek, L.J. Standley, L.M. Hildemann and G.R. Cass (1993). Lignin pyrolysis products, lignans and resin acids as specific tracers of plant classes in emissions from biomass combustion. Environ. Sci. Technol. 27, 2533-2541.

Standley, L.J. and B.R.T. Simoneit (1987). Composition of extractable organic matter in smoke particles from prescribed burns. Environ. Sci. Technol. 21, pp. 163-169.

Standley, L.J. and B.R.T. Simoneit (1990). Preliminary correlation of organic molecular tracers in residential wood smoke with the source of fuel. Atmosph. Environ. 24B, 67-73.

Standley, L.J. and B.R.T. Simoneit (1994). Resin diterpenoids as tracers for biomass combustion aerosols. J. Atmosph. Chem. 18, 1-15.

\section{DISCLAIMER}

\footnotetext{
This report was prepared as an account of work sponsored by an agency of the United States Government. Neither the United States Government nor any agency thereof, nor any of their employees, makes any warranty, express or implied, or assumes any legal liability or responsibility for the accuracy, completeness, or usefulness of any information, apparatus, product, or process disclosed, or represents that its use would not infringe privately owned rights. Reference herein to any specific commercial product, process, or service by trade name, trademark, manufacturer, or otherwise does not necessarily constitute or imply its endorsement, recommendation, or favoring by the United States Government or any agency thereof. The views and opinions of authors expressed herein do not necessarily state or reflect those of the United States Government or any agency thereof.
} 


\section{FIGURE LEGENDS}

Figure 1. Mass fragmentograms for the diterpenoid acids in pine wood smoke $(a, b)$ and the fine particles of the West Los Angeles atmosphere in winter (c,d) (plots are molecular ions of methyl esters, m/z 314 and 316 , numbers refer to compounds in text).

Figure 2. Salient features of a GC-MS analysis of a ketone fraction from a smoke aerosol in Oregon: (a) $\mathrm{m} / \mathrm{z} 58$ fragmentogram, numerals refer to carbon chain length of $n$-alkan-2ones (ip18 =6,10,14-trimethylpentadecan-2-one); (b) total ion current trace (equivalent to GC trace of total fraction), peaks with dots are $n$-alkan-2-ones, peaks with dashes are $n$-alkanals, and the triterpenones are (1) taraxerone, (2) $\beta$-amyrone, (3) lupenone, and (4) a friedelenone.

Figure 3. Representative gas chromatograms of the lipid fractions from an Amazon smoke sample: a) total, b) aliphatic hydrocarbons (F1, early eluting homolog of doublets is the $n$-alk-1ene), c) PAH and esters (F2 + 3), d) ketones (F4), e) dicarboxylic acids and oxy-PAH (F5), and f) alcohols (F6) [ni = carbon numbers of homologous series, additional numbers (i.e., b: $1-6, \mathrm{c}: 1-10$, e,f: $1-12$ ) see text, $\mathrm{U} 1=$ unknown triterpenoid, $F=$ friedelin and IS = internal standard, $\left.n-\mathrm{C}_{24} \mathrm{D}_{50}\right]$.

Figure 4. Salient features of the GC-MS data for the aliphatic hydrocarbons (F1) from an Amazon smoke sample: (a) total ion current trace, (b) alkenes, key ion $\mathrm{m} / \mathrm{z} 83$, (c) alkanes, key ion $\mathrm{m} / \mathrm{z} 99$, (d) triterpenes, key ion $\mathrm{m} / \mathrm{z} 218$ (numbers 18-35 refer to carbon chain length of homologous series and 1-6 are biomarkers, discussed in the text).

Figure 5. Thermal alteration products from amyrins in smoke. 
Figure 6. Salient features of the GC-MS data for the PAH and oxy-PAH in the Amazon smoke sample: (a) PAH in fraction $2+3-$ (1) phenanthrene, (2) 3-methylphenanthrene, (3) 2-methylphenanthrene, (4) 9-methylphenanthrene, (5) 1-methylphenanthrene, (6) fluoranthene, (7) pyrene, (8), (9) chrysene (triphenylene), (10) benzofluoranthenes, (11) benzo(e)pyrene, (12) benzo(a)pyrene, (13) anthanthrene, (14) indeno(1,2,3cd)pyrene, (15) benzo(ghi)perylene; (b) oxy-PAH in fraction 4-(16) $9 H$-fluoren-9one, (17) anthra-9,10-quinone, (18) 4H-cyclopenta(def)phenanthren-4-one, (19) methylanthra-9,10-quinone, (20) $11 \mathrm{H}$-benzo(a)fluoren-11-one, (21) $7 \mathrm{H}$ benzo(c)fluoren-7-one, (22) benz(a)anthra-7,12-quinone, (23) naphthanthrone (6Hbenzo(cd)pyren-6-one). 


\section{F.I}
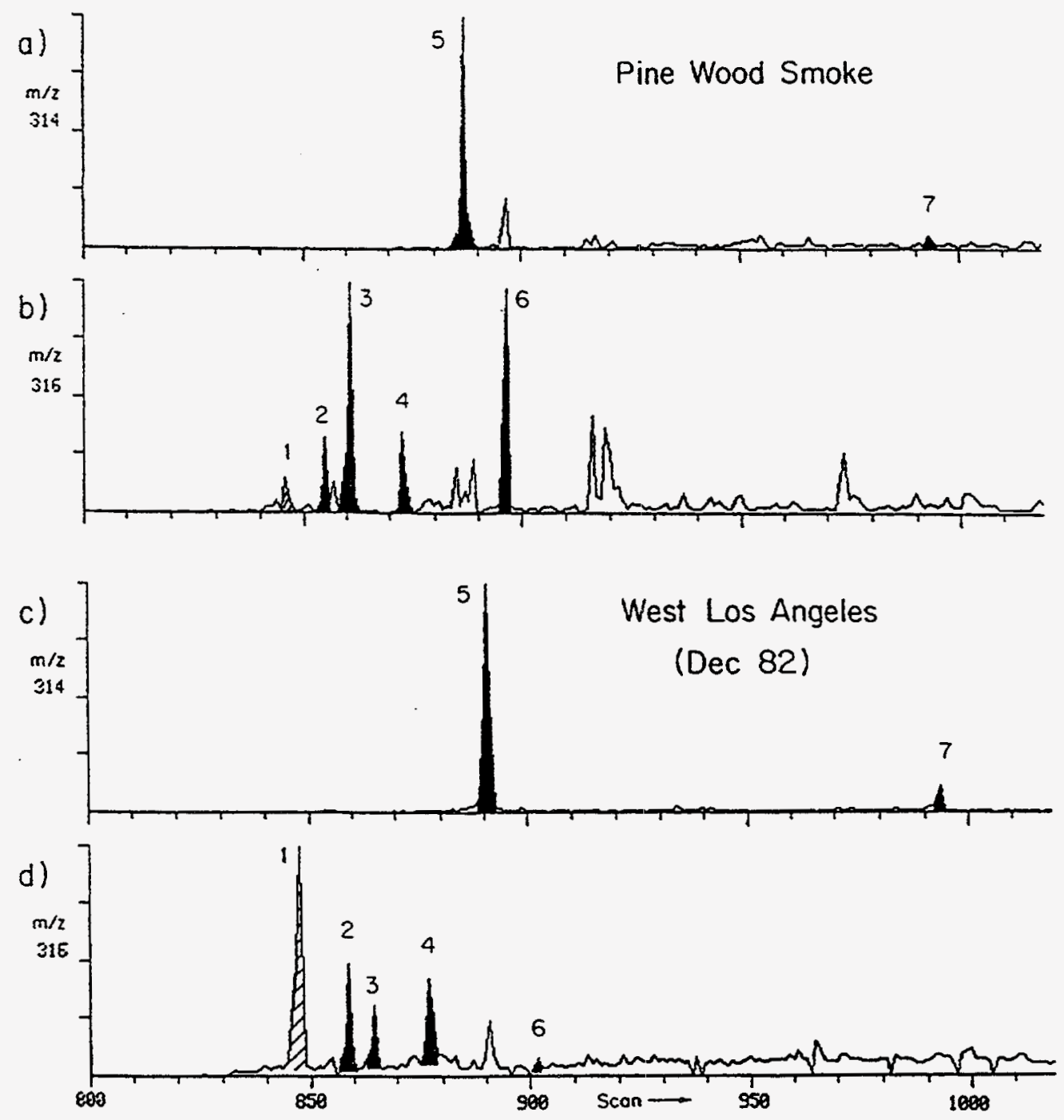

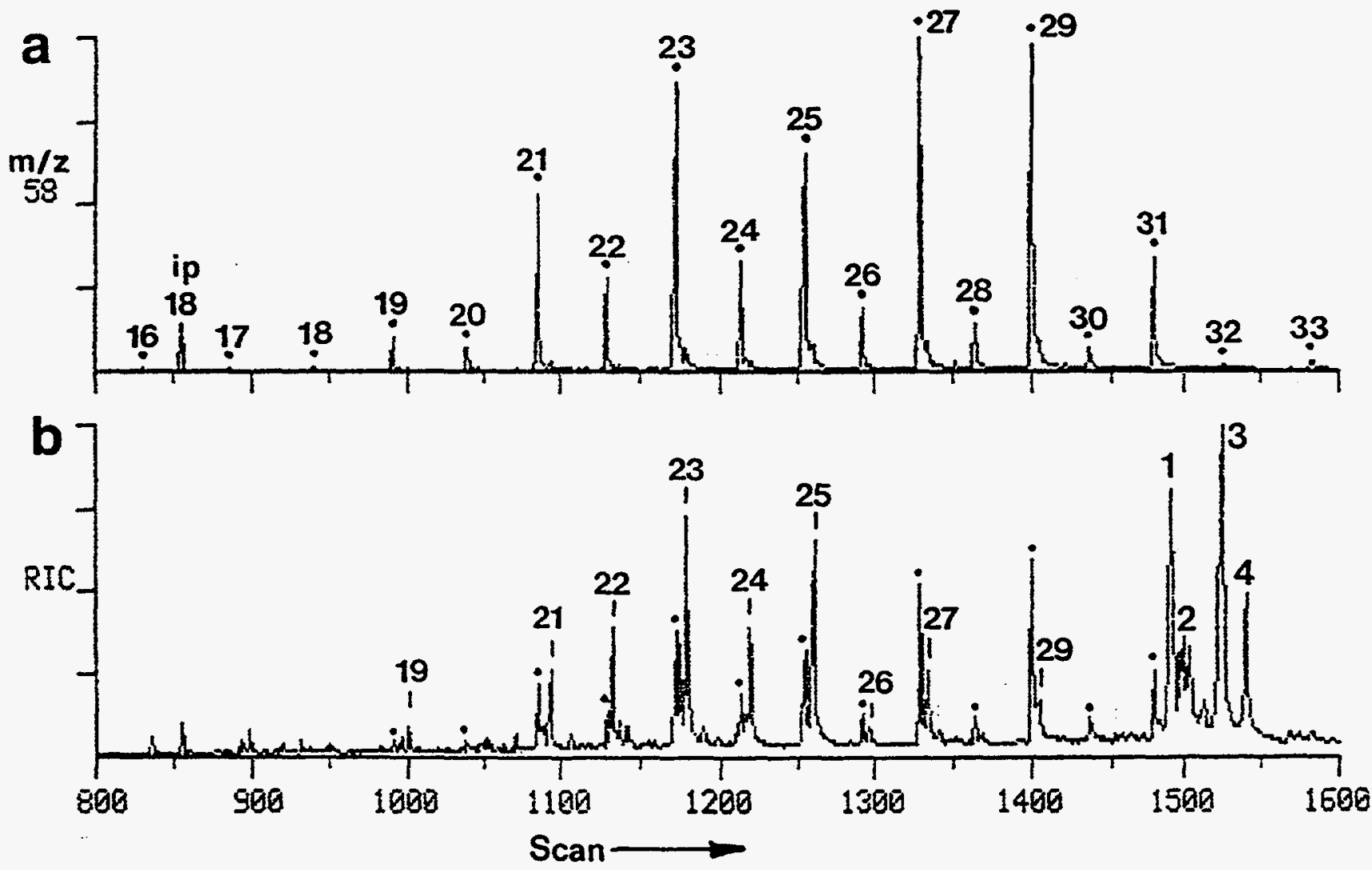

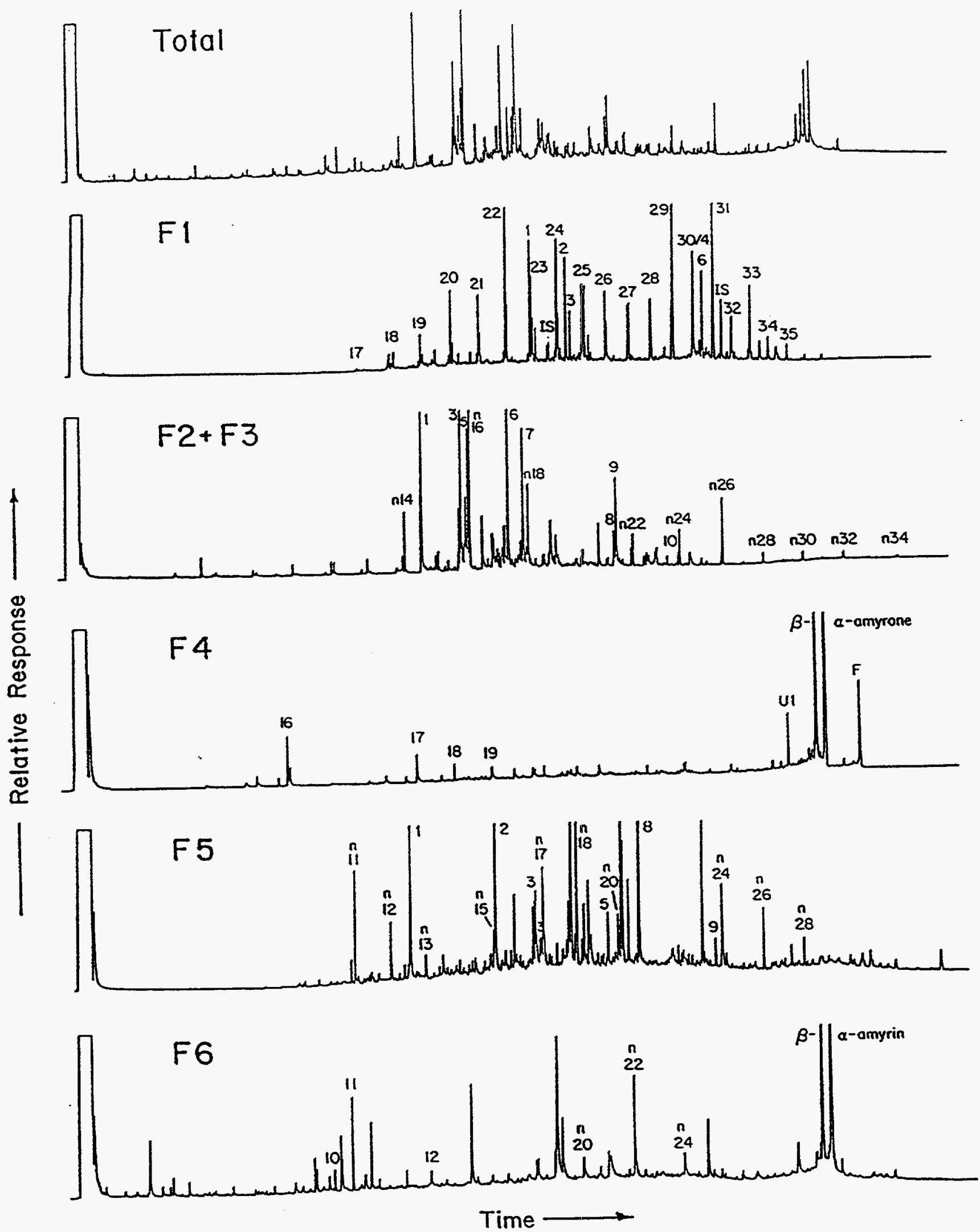
F. 4
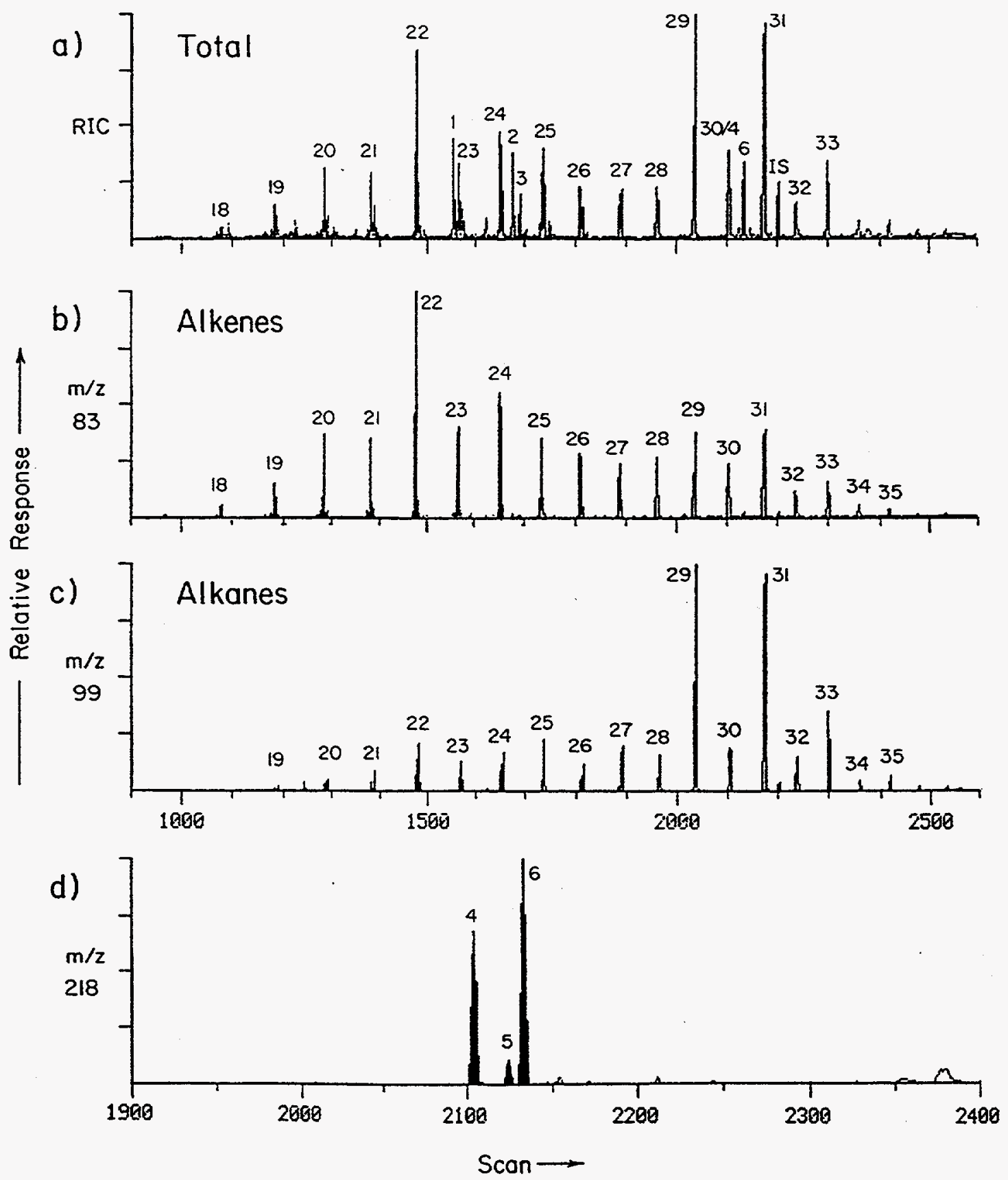


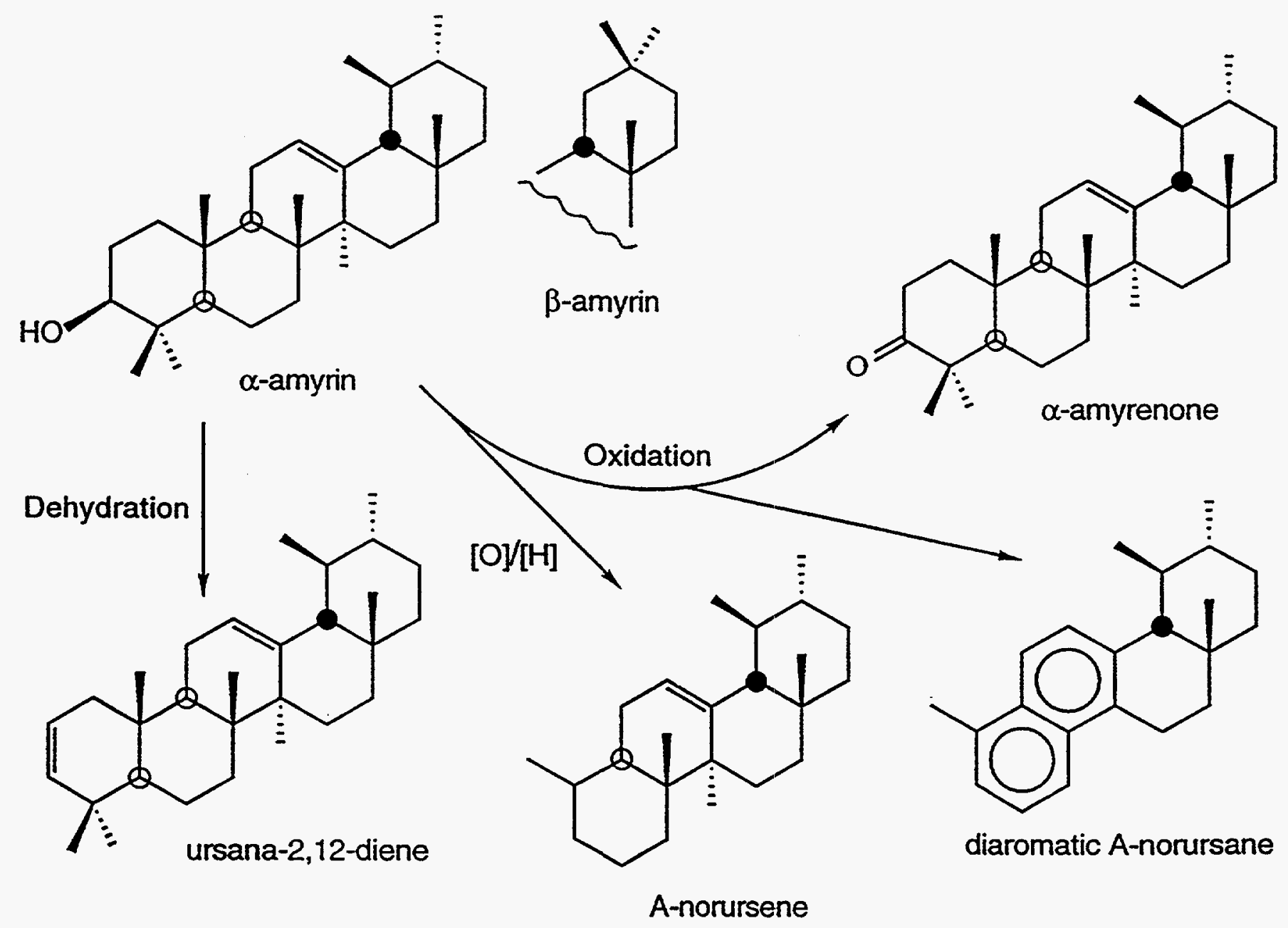


F.G

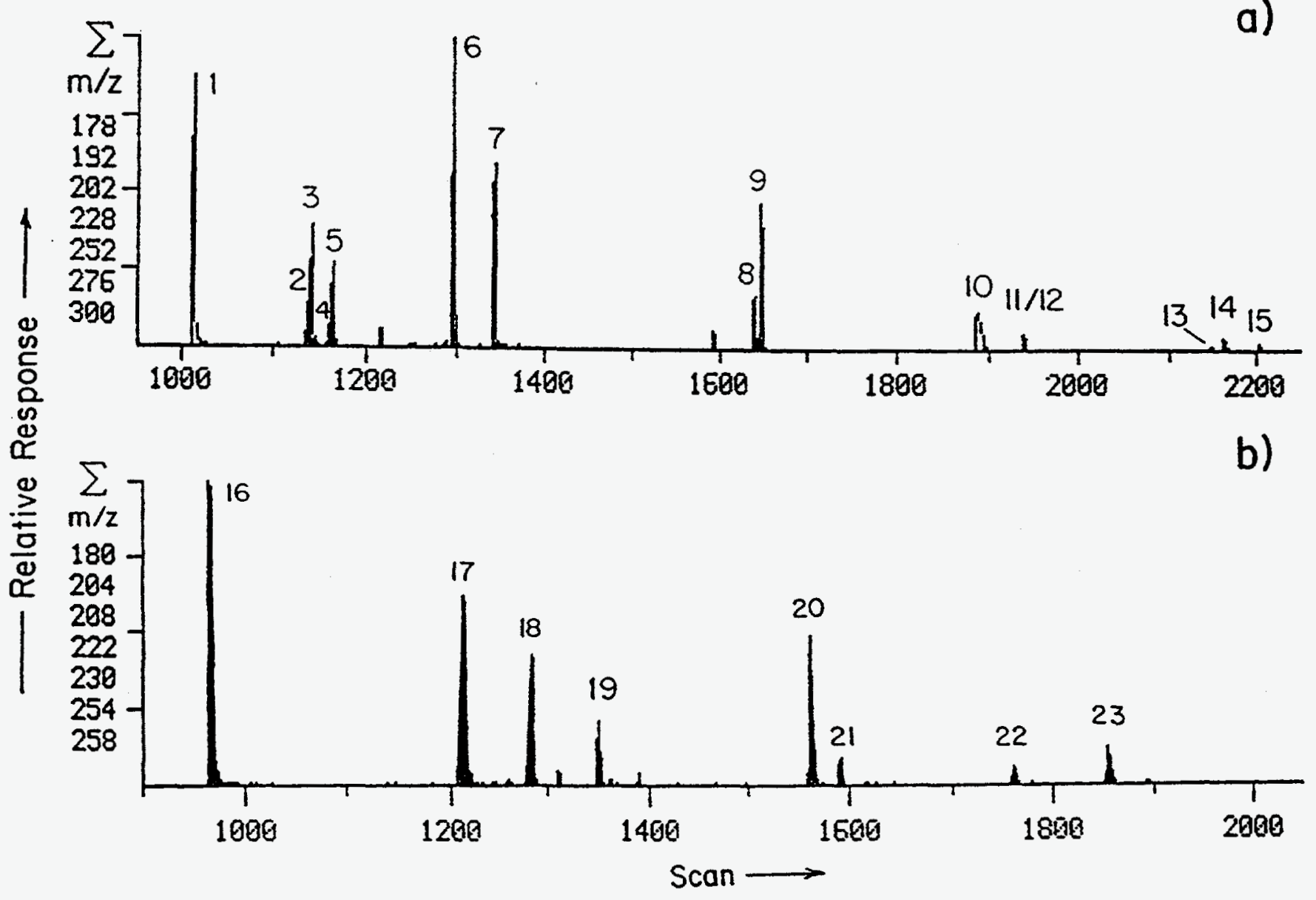




\section{Appendix I: Chemical Structures Cited}

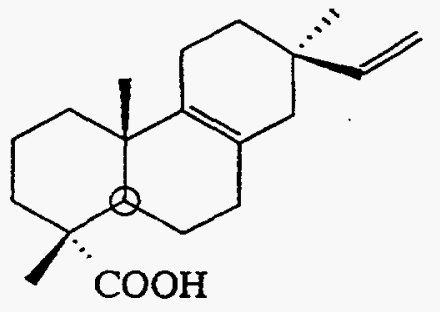

1. $\Delta^{8,15}$-Pimaradien-

18-oic acid<smiles></smiles>

5. Dehydroabietic acid

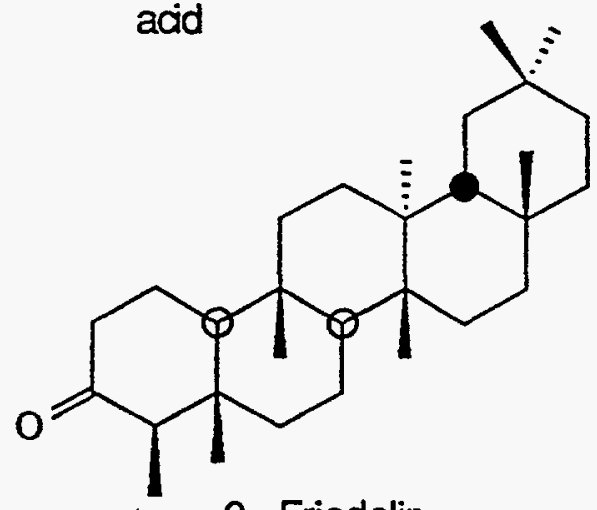

9. Friedelin

2. Pimaric acid<smiles>CC(C)C1=CC2=CCO[C@]3(CCC[C@@](C)(C(=O)O)O3)OC2C1</smiles>

6. Abietic acid

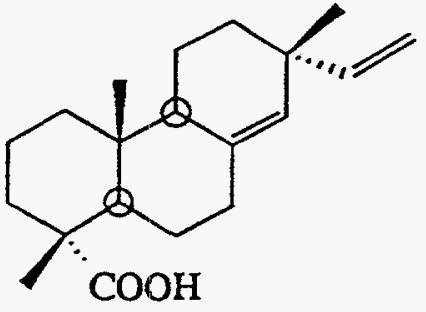

3. Sandaracopimaric

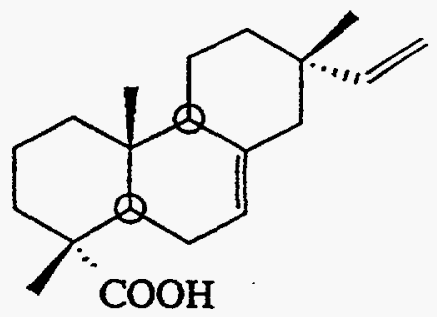

4. Isopimaric acid

acid

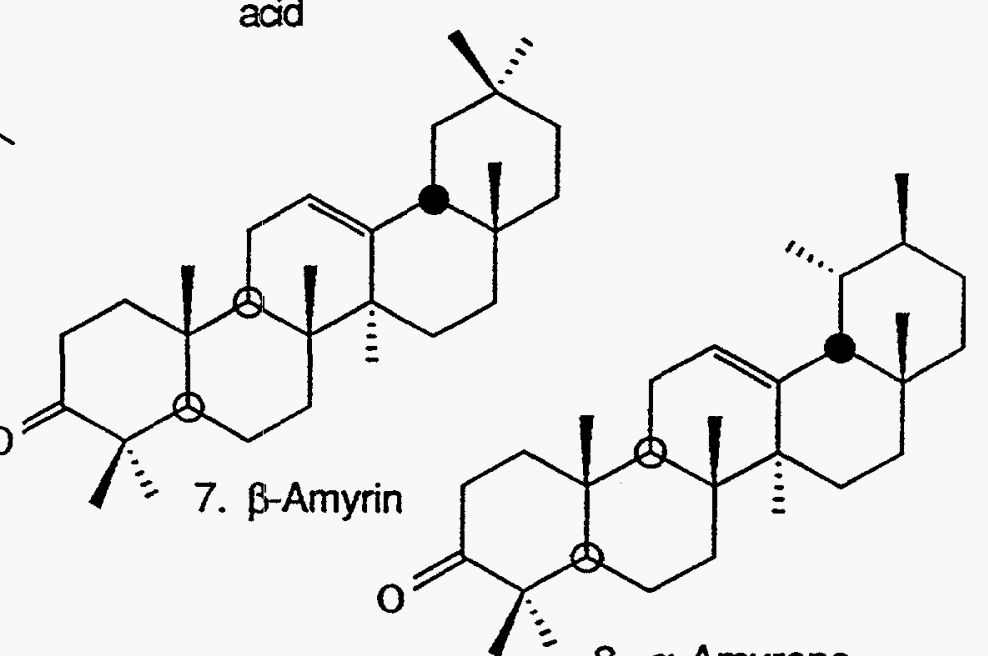

8. $\alpha$-Amyrone Hо

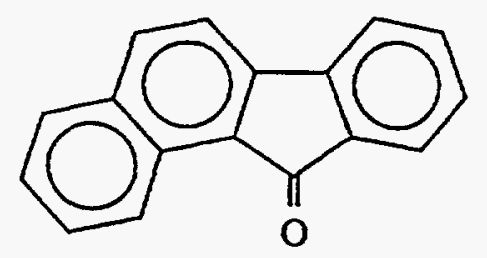

12. Benzo(a)fluoren-11-one<smiles>O=C1c2ccccc2-c2cccc3cccc1c23</smiles>

13. Benzanthrone

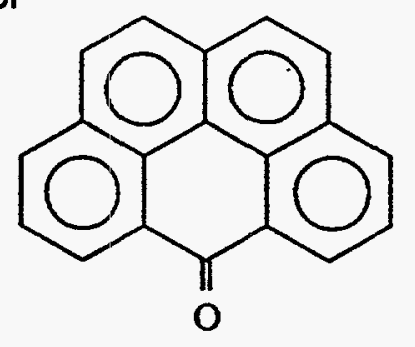

14. Naphthanthrone

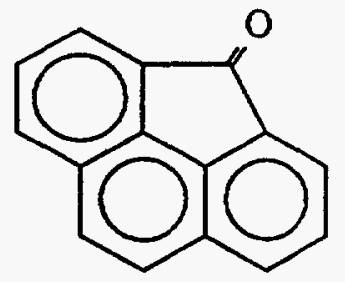

11. Cyclopenta(def)phenanthren-4-one<smiles>COc1cc(C=O)ccc1O</smiles>

15. Vanillin<smiles>COc1cc(C(=O)O)ccc1O</smiles>

17. Syringaldehyde<smiles>COc1cc(C(=O)O)cc(I)c1O</smiles>

$\mathrm{CH}_{3} \mathrm{O}$<smiles>COc1cc(CC(C)=O)ccc1O</smiles>

19. Guaiacyl acetone

18. Syringic acid 